\title{
Rock Mass Classification Applied to Volta Grande Underground Mine Site in Brazil
}

\author{
Daniel Jaques, Klinger Rezende and Eduardo Marques \\ Civil Engineering Department, Viçosa Federal University, Viçosa 36570-000, Brazil
}

\begin{abstract}
Rock mass classification is a key procedure for evaluation of rock mass behavior under underground excavation. This paper presents part of the results of a rock mass classification applied to the Volta Grande mine, located at Nazareno city, Minas Gerais State, Brazil, in order to evaluate its implantation feasibility and to define the most favorable design. Currently, Volta Grande operates an open pit mine in an intrusive pegmatitic body with amphibolite and graphite-rich schist as surrounding rock. All data to be used on RMR and Q classification schemes were collected on twenty-nine boreholes, selected according to their position and to provide an adequate knowledge of both geology and geomechanical characteristics of the project area. However, this paper presents only the results for three boreholes in only one geological cross-section (NS06), considered representative of Volta Grande mine rock mass, as the volume of data from all boreholes is too large. Samples were collected on these boreholes for all rock types and weathering grades, in quantities sufficient to allow physical and mechanical tests and to represent variations in depth and in area. Results show that despite Q system is more sensible to rock type and weathering grade changes when compared to the RMR system, dividing the rock mass in more different compartments, this division did not show good agreement to field and borehole samples observations, as the rock mass do not show such fragmentation and, so, these compartments do not control the overall behavior of the rock mass. As a general result, the rock mass classification results point out that underground mining is feasible for the studied area.
\end{abstract}

Key words: RMR, Q system, underground mining, intact rock, compressive strength, metamorphic rocks.

\section{Introduction}

São João del Rei Pegmatitic Province, which has a $70 \mathrm{~km}$ length and $20 \mathrm{~km}$ width, is located in the southern part of the Minas Gerais state, Southeastern Brazil (Fig. 1). Several important mineral resources - gold, manganese, tin and tantalum have been extracted from this region. Nowadays, only the pegmatitic deposits of the Volta Grande district are currently being mined in an open pit mine (Volta Grande Mine) but there is a geological and geomechanical study under development to evaluate the possibility of underground mining, with excellent results up to now. This paper presents some of the results of this geomechanical study, specifically those from compressive strength tests carried out on surrounding rocks of mineral-rich portions (tin,

Corresponding author: Eduardo Marques, professor, research fields: geological engineering, rock mechanics, and slope stability. tantalum and lithium).

The most common mineral-rich zones are composed of tantalite, columbite and the most important ore is a tantalum concentrate [1]. Presently, the pegmatitic ore has been mined up to a depth of $105 \mathrm{~m}$, after excavation of a thick amphibolite layer of $69 \mathrm{~m}$, resulting in a waste:ore ratio of 7.6:1. As the present design of the open pit is to reach a depth of $175 \mathrm{~m}$, there will be a considerable increase in waste:ore ratio that can restrain open pit mining. So, there is a need of investigate the feasibility of underground mining.

It is well known that rock mass classification is an important and useful tool for feasibility studies, as it composes a simple and economical way of prediction of rock mass behavior, especially in underground excavations [2-6]. Some of the most common proposals of rock mass classifications can estimate self-support time, type and quantity of rock support, and also the optimal geometry of excavation cross-section and rock mining sequence. Although, care 


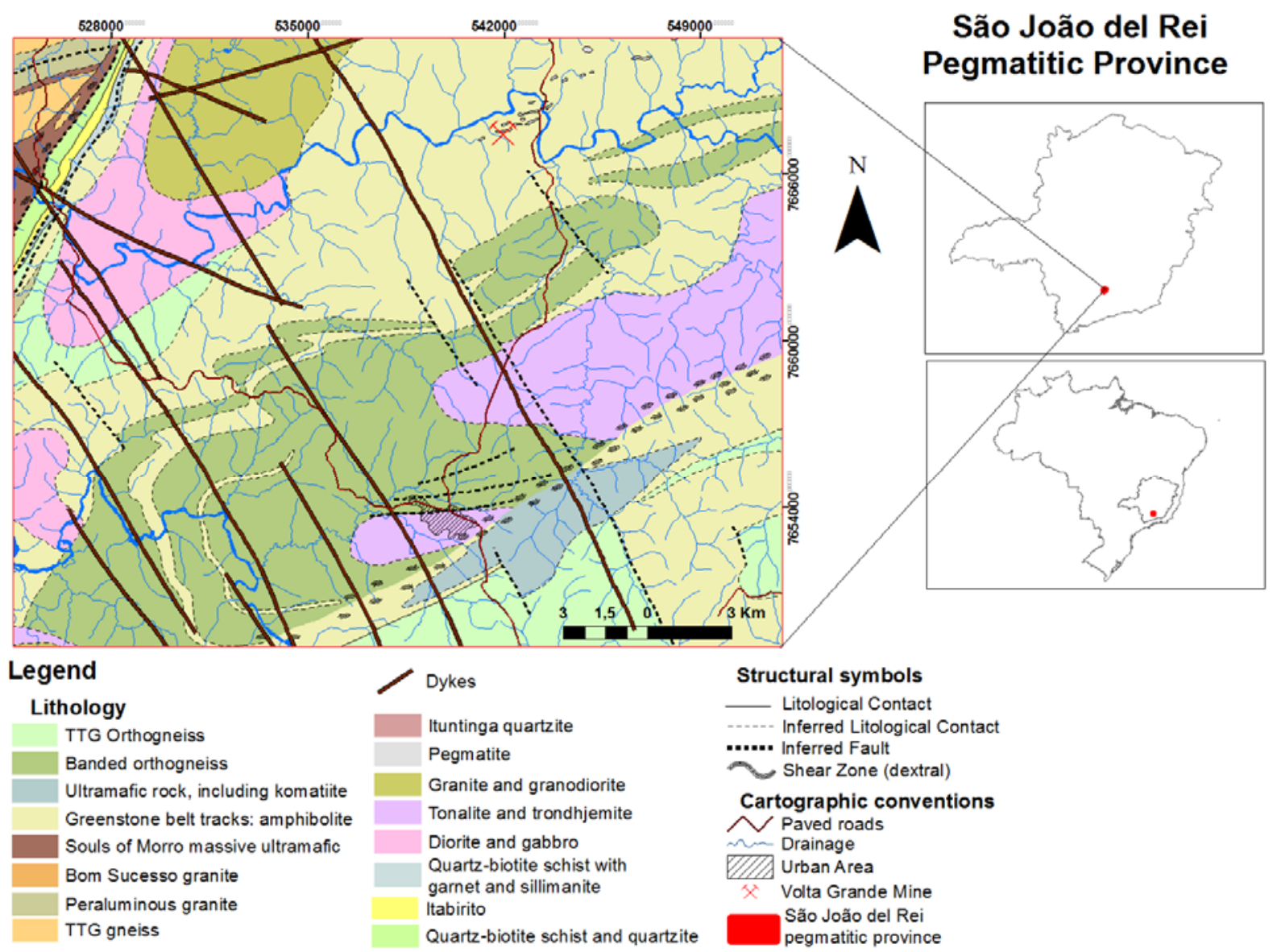

Fig. 1 Location and geological setting of Volta Grande Mine (adapted from Ref. [7]).

must be taken on its use, as pointed out by Ref. [8], as a common misunderstanding between rock mass characterization and rock mass classification sometimes occurs. Also, the classification procedures were developed with the aim of previous and initial design, not for executive projects, as commonly observed in mining practice.

The main purpose of the study was to classify underground rock masses of the area under study, based on borehole description for feasibility development studies for an underground mining.

Even being more laborious, it is recommended that rock mass classification to be performed by using at least two different classification systems, in order to refine data and infer about the better model that can be applied to real (observed) rock mass conditions [9].

The most used rock mass classification systems for underground excavations are the Rock Mass Rating
(RMR), developed by Bieniawski [5, 10] and the Q-system, developed by Refs. [4] and [11]. Both systems use a rating system based on geologic, geometric and design parameters, which can be evaluated through common tests, analysis and measurements. For each parameter a value is given, based on a range of values defined by the systems. At the end, values for all considered parameters are inserted into Eqs. (1)-(2), and the final value, which is related to rock mass quality classes, is then defined.

$$
\mathrm{RMR}=\Sigma \text { (Value of each parameter) - }
$$

Value of adjustment for discontinuity orientation (1) where:

- Intact rock strength;

- RQD — rock quality designation;

- Joint spacing;

- Joint conditions;

- Joint orientation; 
- Underground water conditions.

$$
Q=\left(\mathrm{RQD} / J_{\mathrm{n}}\right) \times\left(J_{\mathrm{r}} / J_{\mathrm{a}}\right) \times\left(J_{\mathrm{w}} / \mathrm{SRF}\right)
$$

where:

- RQD: rock quality designation;

- $J_{\mathrm{n}}$ : number of joints sets;

- $J_{\mathrm{r}}$ : roughness of joint walls;

- $J_{\mathrm{a}}$ : weathering of joint walls;

- $J_{\mathrm{w}}$ : underground water conditions;

- SRF: stress reduction factor.

When comparing results from RMR and $Q$ classifications, it is important to consider that both uses geological and geometric parameters to obtain quantitative values, resulting in qualitative classification of rock masses. Furthermore, it must be highlighted that both systems consider influence of underground water and some joint characteristic (filling and roughness) on rock mass strength. The main differences between these two systems are on rating given to similar parameters, and in the use of one or more parameters from different projects [12]. So, the main differences between these systems are:

- RMR uses uniaxial compressive strength, while $Q$ do not consider this as a parameter;

- RMR considers more parameters related to joints in comparison to $Q$;

- Joint orientation is a parameter used directly in RMR, while in $Q$ this is implicit on $J_{\mathrm{r}} / J_{\mathrm{a}}$ ratio, as these parameters are used for the most unfavorable discontinuity.

The major difference between these systems is, although, the fact that RMR do not consider in situ stress.

\section{Methods}

Previous to the rock mass classification, a rock mass characterization, based on several geological-geotechnical parameters was performed. For this, 29 (twenty-nine) boreholes were detailed described, comprising a total of $3,473 \mathrm{~m}$ of rock characterization. Selection of boreholes was based on its position within the geological cross-section net, in order to provide data for the studied area, both horizontally and vertically. For this present paper only data from one geological cross-section, named NS-06, will be presented in Fig. 2. This cross-section, however, is representative of rock mass generally occurring in the area.

Data collection was systemized through the use of a parameter description sheet and in description, a period of description standardization of each parameter was performed by authors at the site during four months.

RQD determination was strictly based on recommended suggestions, for each drilling maneuver or, when possible, for intervals of equal fracturing intensity [13]. Whenever a lithological contact was present, the RQD determination was limited by this surface. Only at very few specific borehole intervals, RQD determination was restricted by different weathering rock material limits. The same criteria were used to perform the rock mass classification through RMR and $Q$ systems. Rock masses were considered to be dry, and so, no groundwater influence was considered into the rock mass classification. Different rock types were defined by macroscopic analysis. Rock weathering classes were defined based on ISRM suggestions (2007) and all discontinuities were registered and include foliation, faults, veins, lenses and fractures.

After the characterization of all parameters, several samples from each rock and occurring weathering type were selected to be tested for the following parameters: uniaxial and triaxial compressive strength, point load strength, wave velocity propagation and physical characteristics (dry and saturated density, apparent porosity and water absorption capacity). Uniaxial compressive strength (UCS) and point load index (PLI) results were used for rock mass classification, while all other results were used for rock mass characterization. Table 1 resumes all tests and parameters used for rock mass classification and the method used for its determination.

By using an electronic sheet, RMR and Q system classifications were processed by inputting parameters 


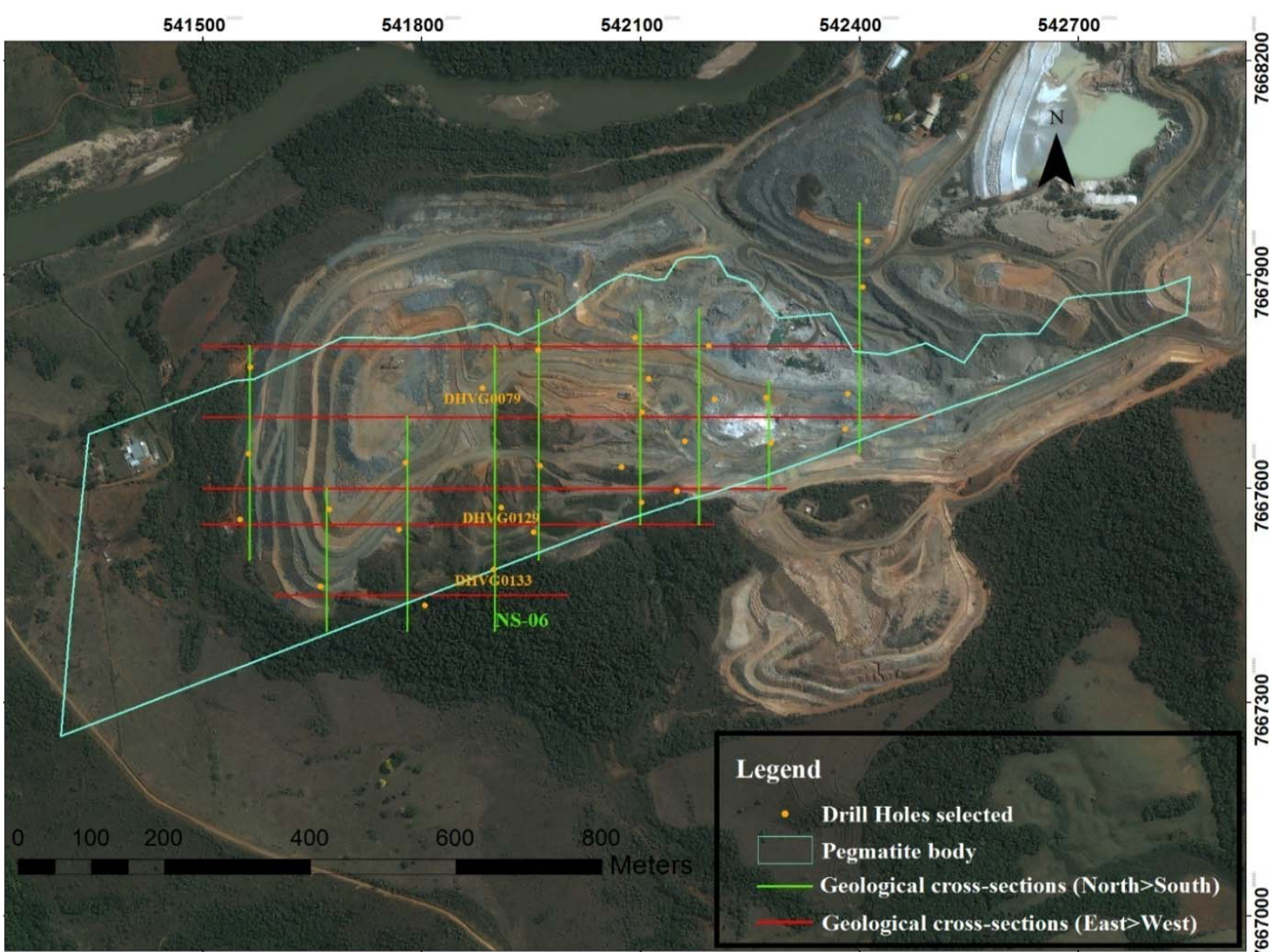

Fig. 2 Location of geological cross-section NS-06 and the drill holes used to interpret the geology and to obtain parameters for rock mass characterization.

Table 1 Parameters and methods used for collection of rock mass classification data [2].

\begin{tabular}{l|l}
\hline Parameter & Method \\
\hline Rock type & Macroscopic description according to ABGE (1998) \\
\hline Joint spacing $(\mathrm{m})$ & Bieniaswki (1989) and Barton et al. (1974) \\
\hline $\begin{array}{l}\text { Joint conditions (aperture, type of filling material, } \\
\text { roughness, persistence, wall weathering) }\end{array}$ & Bieniaswki (1989) and Barton et al. (1974) \\
\hline RQD & Deere et al. (1976) \\
\hline UCS & ISRM (2007) \\
\hline PLT & ISRM (2007) \\
\hline Triaxial & ISRM (2007) \\
\hline Physical properties & ISRM (2007) \\
\hline Wave velocity & ISRM (2007) \\
\hline
\end{tabular}

values for each description interval. After this, all rock mass classes were pondered, in order to allow grouping of rock mass with similar behavior whenever relatively thin different rock class intervals were present inside a more comprehensive and different rock mass class. Finally, rock mass classes were plotted into geological cross sections to allow a better visualization of rock mass distribution.

\section{Results and Discussion}

Section NS-06 represents quite well Volta Grande mine rock mass characteristics and based on that, it was chosen to represent the average rock mass occurring underground. In general, rock masses of Volta Grande 
mine, especially those on pegmatitic body, are mainly formed by sound, coherent rock. The main discontinuities throughout rock failure can occur for underground mining are: foliation - mainly in amphibolite; fractures; disturbed zones related to geological contacts between pegmatite and amphibolite and, finally, disturbed zones related to the Volta Grande fault zone.

Table 2 presents general information about the boreholes used to interpret the geology of this area as well as to perform rock mass classification.

Table 2 General data of boreholes on section NS-06.

\begin{tabular}{lllllll}
\hline Borehole name & $\begin{array}{l}\text { Geographical coordinates } \\
\text { (UTM-SAD69) }\end{array}$ & Elevation $(\mathrm{m})$ & $\begin{array}{l}\text { Drilled length } \\
(\mathrm{m})\end{array}$ & $\begin{array}{l}\text { Unrecovered } \\
\text { length }(\mathrm{m})\end{array}$ & $\begin{array}{l}\text { General } \\
\text { recovering }(\%)\end{array}$ & $\begin{array}{l}\text { Total length } \\
\text { described }(\mathrm{m})\end{array}$ \\
\hline DHVG0079 & $\begin{array}{l}7667741.73 \\
541883.37\end{array}$ & 929.77 & 134.45 & 53.0 & 60.6 & 81.45 \\
DHVG0129 & $\begin{array}{l}7667573.79 \\
541909.09\end{array}$ & 913.25 & 155.95 & 1.50 & 94.0 & 154.45 \\
DHVG0133 & $\begin{array}{l}7667486.37 \\
541898.44\end{array}$ & 905.78 & 269.20 & 15.10 & 94.4 & 254.10 \\
\hline
\end{tabular}

Table 3 Geological-geotechnical description results of boreholes on cross-section NS-06.

\begin{tabular}{|c|c|c|c|c|c|c|c|}
\hline \multirow[t]{2}{*}{ Depth (m) } & \multirow{2}{*}{$\begin{array}{l}\text { Rock } \\
\text { type }\end{array}$} & \multirow[t]{2}{*}{$\begin{array}{l}\text { Weathering } \\
\text { grade* }\end{array}$} & \multicolumn{2}{|c|}{$\begin{array}{l}\text { Compressive } \\
\text { strength }(\mathrm{MPa})\end{array}$} & \multicolumn{2}{|c|}{ RQD (\%) } & \multirow[t]{2}{*}{ Geological description } \\
\hline & & & UCS & PLI & Max. & Min. & \\
\hline \multicolumn{8}{|l|}{ DHVG0079 } \\
\hline $0-53.00$ & - & - & - & - & & & Unrecovered \\
\hline $53-96.05$ & AMP & W1 & 310.49 & - & 100 & 78.4 & $\begin{array}{l}\text { Amphibolite: sound rock, lepidoblastic, fine grained, } \\
\text { foliation (Sn), presence of centimetric quartz veins; } \\
\text { and biotite at the geological contact }\end{array}$ \\
\hline $96.05-111.50$ & PEG & W1 & 90.46 & - & 74.4 & 37.1 & $\begin{array}{l}\text { Pegmatite: sound rock, granoblastic, coarse grained, } \\
\text { presence of centimetric spodumene crystals }\end{array}$ \\
\hline $111.50-134.45$ & AMP & W1 & 310.49 & - & 97.9 & 91.4 & Similar to 2 \\
\hline \multicolumn{8}{|l|}{ DHVG0129 } \\
\hline $0-1.50$ & - & - & & & & & Unrecovered \\
\hline $1.50-11.08$ & AMP & W1 & 310.49 & - & 87.5 & 68.10 & $\begin{array}{l}\text { Amphibolite: sound rock, lepidoblastic, fine grained, } \\
\text { fine foliation }(\mathrm{Sn}) \text {, presence of quartz venules }\end{array}$ \\
\hline $11.08-11.50$ & PEG & W1 & 90.46 & - & 71.4 & - & Similar to 3 \\
\hline $11.50-126.09$ & AMP & W1 & 310.5 & - & 100 & 86.4 & $\begin{array}{l}\text { Similar to } 6 \text { plus: presence of micro-faults, folds; and } \\
\text { biotite in the foliation (Sn) }\end{array}$ \\
\hline $126.09-150.14$ & PEG & W1 & 90.46 & - & 76.1 & 70 & Similar to 7 plus: presence of milky quartz vein \\
\hline $150.14-155.95$ & AMP & W1 & 310.5 & - & 94.4 & 23.2 & Similar to 8 \\
\hline \multicolumn{8}{|l|}{ DHVG0133 } \\
\hline $0-15.10$ & - & - & - & - & - & - & Unrecovered \\
\hline $15.10-50.00$ & GRS & W2 & - & 2,7 & 52.8 & 11.9 & $\begin{array}{l}\text { Graphite-rich schist: near Volta Grande shear zone } \rightarrow \\
\text { disturbed foliation with presence of iron and } \\
\text { manganese oxides, granolepidoblastic, medium } \\
\text { grained, presence of amphibolite intercalations }\end{array}$ \\
\hline $50.00-58.70$ & AMP & $\mathrm{W} 2 / \mathrm{W} 3$ & - & 1,7 & 66.3 & - & $\begin{array}{l}\text { Similar to } 6 \text { plus: disturbed foliation, GRS } \\
\text { interleaving, presence of sulfides }\end{array}$ \\
\hline $58.70-87.25$ & AMP & W1 & 310.5 & - & 100 & 89.6 & Similar to 13 plus: presence of micro faults \\
\hline $87.25-104.75$ & GRS & W2 & 39.65 & - & 88.9 & - & Similar to 12 \\
\hline $104.75-122.50$ & AMP & W1 & 310.5 & - & 100 & 50 & Similar to 13 \\
\hline $122.50-128.80$ & GRS & W2 & 39.65 & - & 89.4 & - & Similar to 12 \\
\hline $128.80-163.95$ & AMP & W1 & 310.5 & - & 100 & 92.3 & Similar to 14 \\
\hline $163.95-171.10$ & GRS & W2 & 39.65 & - & 100 & 89.7 & Similar to 12 \\
\hline $171.10-269.20$ & AMP & W1 & 310.5 & - & 100 & 56 & Similar to 14 \\
\hline
\end{tabular}

* (ISRM, 2007). UCS and PLI results are the average values determined for each rock type, based on several UCS tests results. W1: sound rock; W2: slightly weathered rock; W3: moderately weathered rock. 
Table 4 RMR and $Q$ rock mass classification for each described borehole.

\begin{tabular}{|c|c|c|c|c|c|}
\hline \multirow{2}{*}{$\begin{array}{l}\text { DHVG0079 } \\
\text { RMR system } \\
\end{array}$} & & \multicolumn{2}{|l|}{ DHVG0129 } & \multicolumn{2}{|l|}{ DHVG0133 } \\
\hline & & & & & \\
\hline Depth (m) & Grade & Depth (m) & Grade & Depth (m) & Grade \\
\hline $0.0-53.00$ & ${ }^{1} \mathrm{NR}$ & $0.00-1.50$ & NR & $0.0-15.10$ & NR \\
\hline $53.00-96.05$ & I & $1.50-11.50$ & II & $15.10-58.7$ & III \\
\hline $96.05-111.50$ & II & $11.50-117.85$ & II & $58.70-87.25$ & I \\
\hline \multirow[t]{4}{*}{$1.50-134.45$} & I & $117.85-155.95$ & II & $87.25-104.75$ & II \\
\hline & & & & $104.75-188.55$ & I \\
\hline & & & & $188.55-206.60$ & II \\
\hline & & & & $206.60-269.20$ & I \\
\hline \multicolumn{6}{|l|}{ Q system } \\
\hline Depth (m) & Grade & Depth (m) & Grade & Depth (m) & Grade \\
\hline $0.0-53.00$ & NR & $0.0-1.50$ & NR & $0.0-15.10$ & NR \\
\hline $53.0-70.25$ & II & $1.50-11.08$ & IV & $15.10-58.70$ & VI \\
\hline $70.25-93.70$ & II & $11.08-36.80$ & II & $58.70-79.75$ & III \\
\hline $93.70-111.50$ & IV & $36.80-113.60$ & III & $79.75-104.75$ & IV \\
\hline \multirow[t]{4}{*}{$111.50-134.45$} & III & $113.60-155.95$ & IV & $104.75-146.85$ & III \\
\hline & & & & $146.85-188.55$ & II \\
\hline & & & & $188.55-221.40$ & IV \\
\hline & & & & $221.40-269.20$ & II \\
\hline
\end{tabular}

${ }^{1} \mathrm{NR}-$ Not recovered.

Three rock types occur in NS-06 geological cross-section: AMP (amphibolite), PEG (pegmatite) and GRS (graphite-rich schist). Table 3 presents geological-geotechnical descriptions of boreholes on section NS-06.

Based on the results of mechanical and physical rock lab characterization tests presented on Table 3 , the rock mass classes identified (Table 4) for each system (RMR or Q) on section NS-06, are:

- RMR: I (Very Good Rock), II (Good Rock) and III (Fair Rock);

- Q-System: I (Exceptionally Good), II (Extremely Good), III (Very Good), IV (Good) and VI (Poor).

Amphibolite and pegmatite intact rock have, in general, presented high to very high uniaxial compressive strength, while schist has a lower intact rock strength.

By using RMR classification system, the following classes were identified in the NS-06 cross section zone: Class I (very good rock), Class II (good rock) and Class III (fair rock). It must be pointed that no correction regarding excavation direction and its relation to the orientation of main discontinuity could be performed.

Class I rock masses correspond to sound rock intervals, with no fracturing, predominantly at greater depths. Class II rock masses with RMR values vary between 62 and 80 . Rocks with lower RMR values are normally associated with lightly to moderately weathered rock, having moderate coherence, while greater values are associated with sound rock, coherent, but showing some fracturing. The main difference between rock mass Class I and rock mass Class II with high RMR values (close to 80 ) is mainly due to rock fracturing and, because of that, lower RQD values.

Despite being less frequent, Class III rock masses (RMR between 50 and 60) are mainly associated with moderately weathered rock, moderate to low coherence and, normally, related to weathering zones close to the surface or close to the Volta Grande tectonic fault or geological contacts, especially when graphite-rich schist is present. Fracturing is intense and shear strength should not be high, as discontinuities generally present weathered walls and low rugosity. Some 
discontinuities also show filling.

By using the $Q$ system, the following rock mass classes were identified: Class I (exceptional good quality rock mass), Class II (extremely good quality rock mass), Class III (very good quality rock mass), Class IV (good quality rock mass) and Class VI (poor quality rock mass).

The worst rock mass classes identified (Class III for RMR and class VI for $Q$ system) represent only $8.9 \%$ of the total length of boreholes with sample recovering.

An attempt to correlate rock mass classes from both systems was performed and the results are:

- RMR class I = $Q$ classes I e II;

- RMR class II = $Q$ classes III e IV;

- RMR class III = $Q$ classes V e VI.

The result of rock mass classification along cross-section NS-06 is presented on Figs. 3-4, for RMR and $Q$ systems, respectively.

Another important behavior observed was that RMR classes identified are more uniform along boreholes with few abrupt variations for small boreholes intervals. The most influent parameter for RMR variation within Volta Grande area was RQD. This behavior was not observed for the Q system, which has shown to be more sensitive to variations of RQD, $J_{\mathrm{n}}, J_{\mathrm{r}}$ and $J_{\mathrm{a}}$ parameters. The same behavior was in a study comparing RMR and $Q$ systems, and has determined that the $Q$ system is more sensitive to variations of field parameters such as RQD, $J_{\mathrm{n}}$ and $J_{\mathrm{r}}$, when compared to the RMR system [15]. Differences on application of both systems to the same study area result in different classes mainly because each system seems to independently select the main factors and take into account the rating of parameters [16].

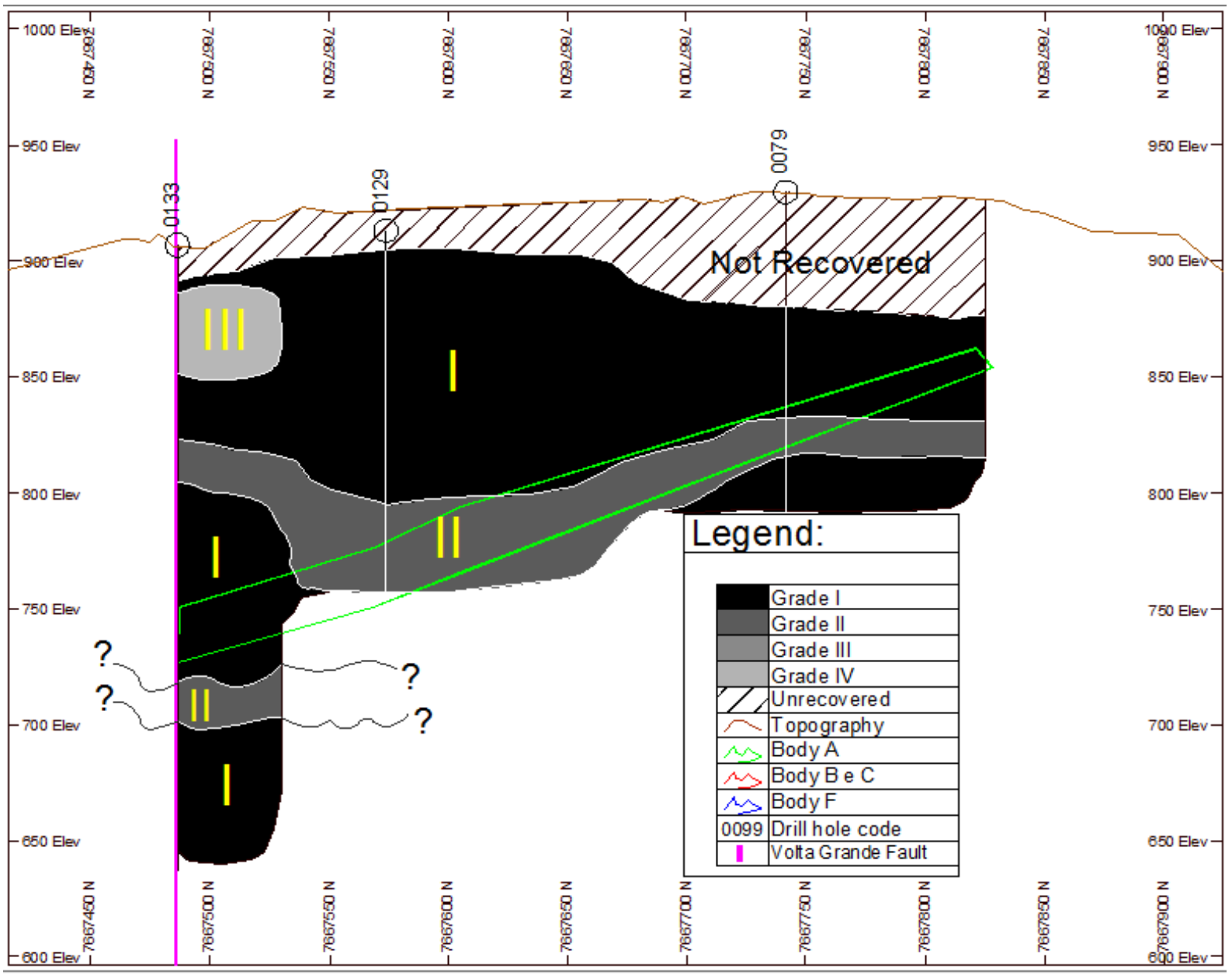

Fig. 3 Rock mass classification of NS-06 cross section, accordingly to RMR system. 


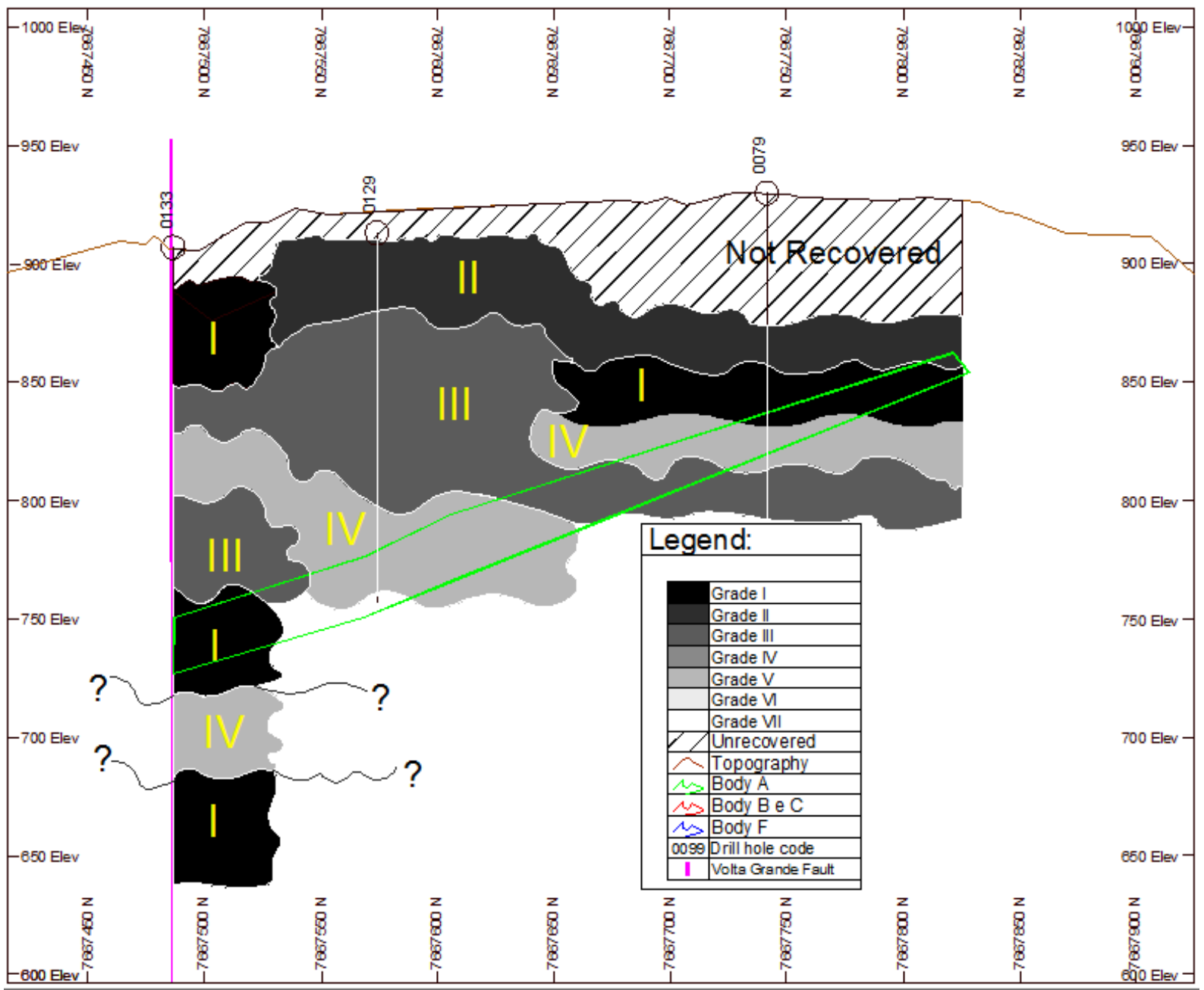

Fig. 4 Rock mass classification of NS-06 cross section, accordingly to $Q$ system.

Comparison of results obtained for RMR and $Q$ systems applied to Volta Grande mine rock mass, showed that RMR seems to more precisely represent the average expected behavior of rock mass, as observed in the field, while the $Q$ system has proved to better detect small variations of rock mass characterization parameters. In a study using both systems to classify a rock mass for slope stability in India, it was concluded that RMR system allows a better general comprehension of rock masses under study, when comparing to $Q$ system, which commonly results in an excessively partitioned and small rock mass classes, which are commonly related to gradational geological contacts rather than different mechanical behavior [17]. A question that results from this consideration is: if two different systems were used in two different project locations, it would be possible to compare their rock mass classification results [18].

Therefore, for the specific feasibility design purposes of Volta Grande underground mine, it can be stated that the RMR system provides a more useful and simple rock mass classification, mainly because of the average good quality of its rock mass. However, for zones with more stress influence, the $Q$ system should be used to provide a better definition of rock support for these zones and to identify possible failure zones.

\section{Conclusions}

The main conclusions that can be done from the results obtained in the study are:

The proposed approach used has proved to be useful and reliable for the rock mass classification of Volta 
Grande mine area;

RMR system has proved to be the best to be used for viability and design studies of the study area, as for feasibility studies the general behavior of the rock mass is more important. Small variations of rock mass classes can be later used for more specific design;

Rock mass classes observed in Volta Grande mine are generally of good quality, regardless of the rock mass classification system used, and, because of that, this result points out to the feasibility of using it in a conceptual design of an underground mining project for the study area.

\section{Acknowledgments}

The authors would like to thank the geologist engineers of AMG Mineração for allowing the development the research and to CAPES for the student grant.

\section{References}

[1] Pereira, R. M., Ávila, C. A., and Neumman, R. 2004. "Mineralogical and Chemical Study of Cassiterite and its Solid Inclusions: Implications with Mineralogical Paragenesi of São João Del Rei Pegmatitic Province, Minas Gerais State, Brazil." Arquivos do Museu Nacional 62: 321-36.

[2] Matula, M. 1981. "Rock and Soil Description and Classification for Engineering Geological Mapping." Bulletin of the International Association of Engineering Geology and the Environment 24: 235-74.

[3] Brazilian Association of Engineering and Environmental Geology. 1998. "Associação Brasileira de Geologia de Engenharia e ambiental." Geologia de Engenharia, 587. [S.1.]: ABGE/FAPESP/CNPq.

[4] Barton, N., Lien, R., and Lunde, J. 1974. "Engineering Classification of Rock Masses for the Design of Tunnel Support.” Rock Mechanics 6 (4): 189-239.

[5] Bieniawski, Z. T. 1989. Engineering Rock Mass Classifications. New York: John Wiley \& Sons, 251.

[6] Hoek, E., and Brown, E. T. 1980. Underground
Excavations in Rock. London: Inst. Min. Metal, 526.

[7] Codemig. 2013. Geological Map_Lavras Layer. 1 Map. Color. Scale: 1:100,000. Available in: http://www.codemig.com.br/site/content/parcerias/mapas/ Lavras.zip.

[8] Potvin, Y., Dight, P. M., and Wesseloo, J. 2012. "Some Pitfalls and Misuses of Rock Mass Classification Systems for Mine Design." The Journal of the South African Institute of Mining and Metallurgy 112 (8): 697-702.

[9] Stille, H., and Palmström, A. 2002. "Classification as a Tool in Rock Engineering." Tunnelling and Underground Space Technology 18: 331-45.

[10] Bieniawski, Z. T. 1974. "Estimating the Strength of Rock Materials." Journal of the South African Institute of Mining and Metallurgy 74 (8): 312-20.

[11] Barton, N., Lien, R., and Lunde, J. 1974. "Engineering Classification of Rock Masses for the Design of Tunnel Support." Rock Mechanics 6 (4): 189-239.

[12] Hoek, E. 2000. Pratical Rock Engineereing, 47.

[13] Deere, D. U. 1989. Rock Quality Designation (RQD) after 20 Years. U.S. Army Corps Engrs Contract Report. Vicksburg, MS: Waterways Experimental Station. GL-89-1.

[14] International Society for Rock Mechanics. 2007. “The Complete ISRM Suggested Methods for Characterization, Testing and Monitoring: 1974-2006." In Suggested Methods Prepared by the Commission on Testing Methods, edited by Ulusay, R., and Hudson, J. A. Ankara, Turkey: ISRM, Turkish National Group, 628.

[15] Holmoy, K. H., Nilsen, B., Olsen, V., Panthi, K. K., and Shrestha, G. L. 2003. "RMR vs. Q vs. RMi.” Tunnels \& Tunnelling International 35 (5): 45.

[16] Rahmannejad, R., and Mohammadi, H. 2007. "Comparison of Rock Mass Classification Systems." Journal of Mining Science 43 (4): 404-8.

[17] Sarkar, S., Kanungo, D. P., and Kumar, S. 2012. "Rock Mass Classification and Slope Stability Assessment of Road Cut Slopes in Garhwal Himalaya, India." Geotech Geol. Eng 30: 827-40.

[18] Hashemi, M., Moghaddas, S., and Ajalloeian, R. 2010. "Application of Rock Mass Characterization for Determining the Mechanical Properties of Rock Mass: A Comparative Study." Rock Mechanics and Rock Engineering 43: 305-20. 